\title{
Inhibition of listeriolysin 0 and phosphatidylcholine-specific production in Listeria monocytogenes by subinhibitory concentrations of plant essential oils
}

\author{
A. SMITH-PALMER*, J. STEWART† and L. FYFE* \\ * Department of Dietetics, Nutrition and Biological Sciences, Queen Margaret University College, Clerwood \\ Terrace, Edinburgh EH12 8TS and †Department of Medical Microbiology, University of Edinburgh Medical \\ School, Teviot Place, Edinburgh EH8 9AG
}

\begin{abstract}
Successful infection by Listeria monocytogenes is dependent upon a range of bacterial extracellular proteins including a cytolysin termed listeriolysin $O$ and phosphatidylcholine-specific phospholipase C. Five plant essential oils - bay, clove, cinnamon, nutmeg and thyme - significantly reduced the production of listeriolysin $\mathrm{O}$ by $L$. monocytogenes. The greatest change was observed after culture with oil of thyme, which reduced haemolysis to 52.1 haemolytic units $(\mathrm{HU}) / \mathrm{ml}$ compared with $99.8 \mathrm{HU} / \mathrm{ml}$ observed with the control. Oil of clove was the only oil that also significantly reduced phosphatidylcholine-specific phospholipase $C$ activity. These changes were observed despite the oils causing no change to the final bacterial concentration or total extracellular protein concentration.
\end{abstract}

\section{Introduction}

Listeria monocytogenes is the bacterium responsible for listeriosis, a disease with potentially serious complications including miscarriage, pre-term labour, meningitis and bacteraemia, and a mortality rate which can be as high as $30 \%$ [1]. Pregnancy is recognised as an important predisposing condition for L. monocytogenes infection. In non-pregnant adults, listeriosis occurs principally in those with a suppressed immune system. Predisposing conditions include lymphoproliferative disorders (leukaemia and lymphoma), other malignancies and immunosuppressive therapy associated with transplants [2]. The elderly are also at increased risk, as are patients with AIDS [3]. However, up to $30 \%$ of adults who develop listeriosis have no apparent immunocompromising condition [4].

L. monocytogenes is a gram-positive facultative intracellular pathogen capable of infecting a range of host cells including macrophages, fibroblasts and epithelial

Received 15 March 2001; revised version accepted 22 Oct. 2001.

Corresponding author: Dr L. Fyfe.

* Present address: Department of Biological Sciences, HeriotWatt University, Riccarton, Edinburgh EH14 4AS. cells, by a process termed 'parasite-directed endocytosis' or 'induced phagocytosis'. InlA and InlB are two surface-bound proteins required for the invasion of many, but not all, non-phagocytic cell types [5]. A protein designated p60 is also involved in this process. Although predominately an extracellular protein, some p60 is also associated with the cell wall [6]. The subsequent survival and cell-to-cell spread of L. monocytogenes is dependent upon a range of extracellular proteins including catalase, superoxide dismutase, phosphatidylcholine-specific phospholipase C, phosphatidylinositol-specific phospholipase C [7-9] and listeriolysin $\mathrm{O}$ [10]. Listeriolysin $\mathrm{O}$ is a $60-\mathrm{kDa}$ toxin belonging to the family of thiol-activated cytolysins. It disrupts the phagocytic membrane, allowing bacterial escape from the endosomal compartment. Following escape from the vacuole, L. monocytogenes induces host cell actin polymerisation which propels the bacteria through the host cell cytoplasm, ultimately leading to the formation of projections which are engulfed by neighbouring cells [11]. A number of the extracellular proteins are implicated in escape from the resultant double membrane vacuoles, especially the phospholipases.

The antimicrobial properties of herbs and spices have been recognised for many thousands of years. Recently 
there has been renewed interest in these products, in particular essential oils, in both the food and pharmaceutical industries [12-14]. As well as having antimicrobial properties, research has also shown that essential oils have the ability to alter bacterial pathogenicity and, in particular, toxin production. The work of González-Fandos et al. [15] demonstrated the influence of garlic on enterotoxin production by Staphylococcus aureus. Similarly, De Wit et al. [16] reported that garlic inhibited type A toxin production by Clostridium botulinum. However, data are unavailable regarding any changes in extracellular protein production by L. monocytogenes, despite considerable literature on the antilisterial properties of plant essential oils $[13,17]$. This study investigated the ability of subinhibitory concentrations of selected plant essential oils to decrease the production of listeriolysin $\mathrm{O}$ and phosphatidylcholine-specific phospholipase $\mathrm{C}$ in vitro.

\section{Materials and methods}

\section{Micro-organism}

Listeria monocytogenes NCTC 11994 was maintained on Tryptone Soya Agar (Oxoid) at $4^{\circ} \mathrm{C}$.

\section{Preparation of cultures and culture supernates}

A $10-\mu 1$ volume of an overnight culture of L. monocytogenes was used to inoculate $10 \mathrm{ml}$ of tryptone soya broth (TSB) containing subinhibitory concentrations of plant essential oils of bay (Pimenta racemosa), cinnamon leaf (Cinnamomum verum), clove stem (Syzygium aromaticum) and thyme (Thymus vulgaris) at $0.01 \% \mathrm{v} / \mathrm{v}$, and oil of nutmeg (Myristica fragrans) at $0.0025 \% \mathrm{v} / \mathrm{v}$ (kindly supplied by F.D. Copeland and Sons, London). Figs. 1-5 show the gas chromatography profiles of the plant essential oils and their major constituents. These five plant essential oils had previously been reported to have good antimicrobial activity against L. monocytogenes [13]. These subinhibitory concentrations were selected as they ensured that the bacterial concentration in the experimental samples after $24 \mathrm{~h}$ was the same as the control. Supernates from 24-h cultures were obtained by centrifugation $(1600 \mathrm{~g})$ for $10 \mathrm{~min}$.

\section{Determination of extracellular protein concentration}

The determination of extracellular protein concentration was based on the method of Bradford [18] with Coomassie Brilliant Blue $\mathrm{G}$ dye (BioRad), diluted 1 in 5 , and bovine serum albumin (Sigma-Aldrich) as the standard. Five $\mathrm{ml}$ of dye reagent were added to 1-ml samples of culture supernates and incubated at room temperature for $30 \mathrm{~min}$. Absorbance was read in triplicate at $595 \mathrm{~nm}$ with a Dynatech MR 500 plate reader. Controls included TSB alone, the value for which was subtracted from the experimental value, to give the extracellular protein concentration.

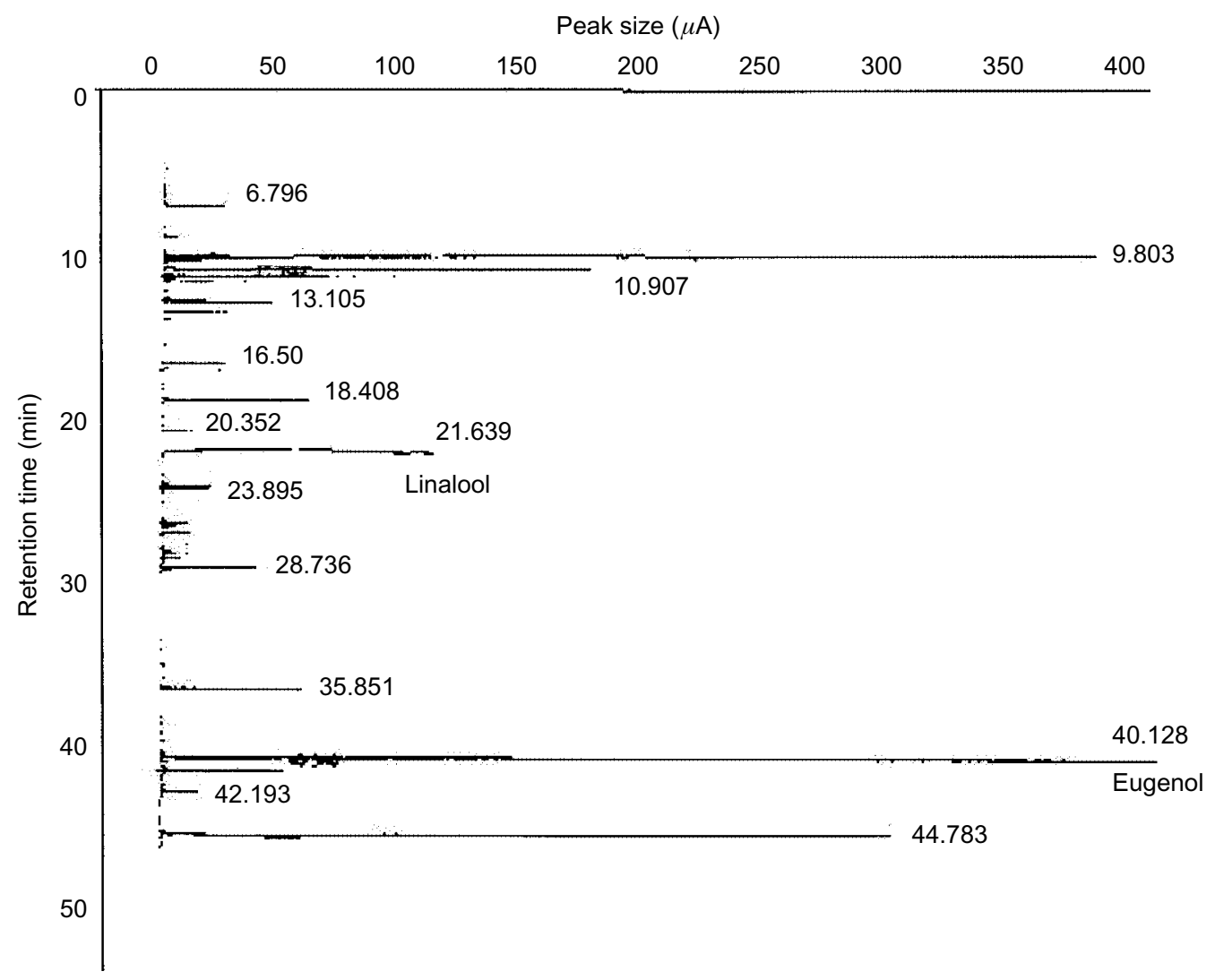

Fig. 1. Gas chromatography report for the composition of oil of bay (Pimenta racemosa). 


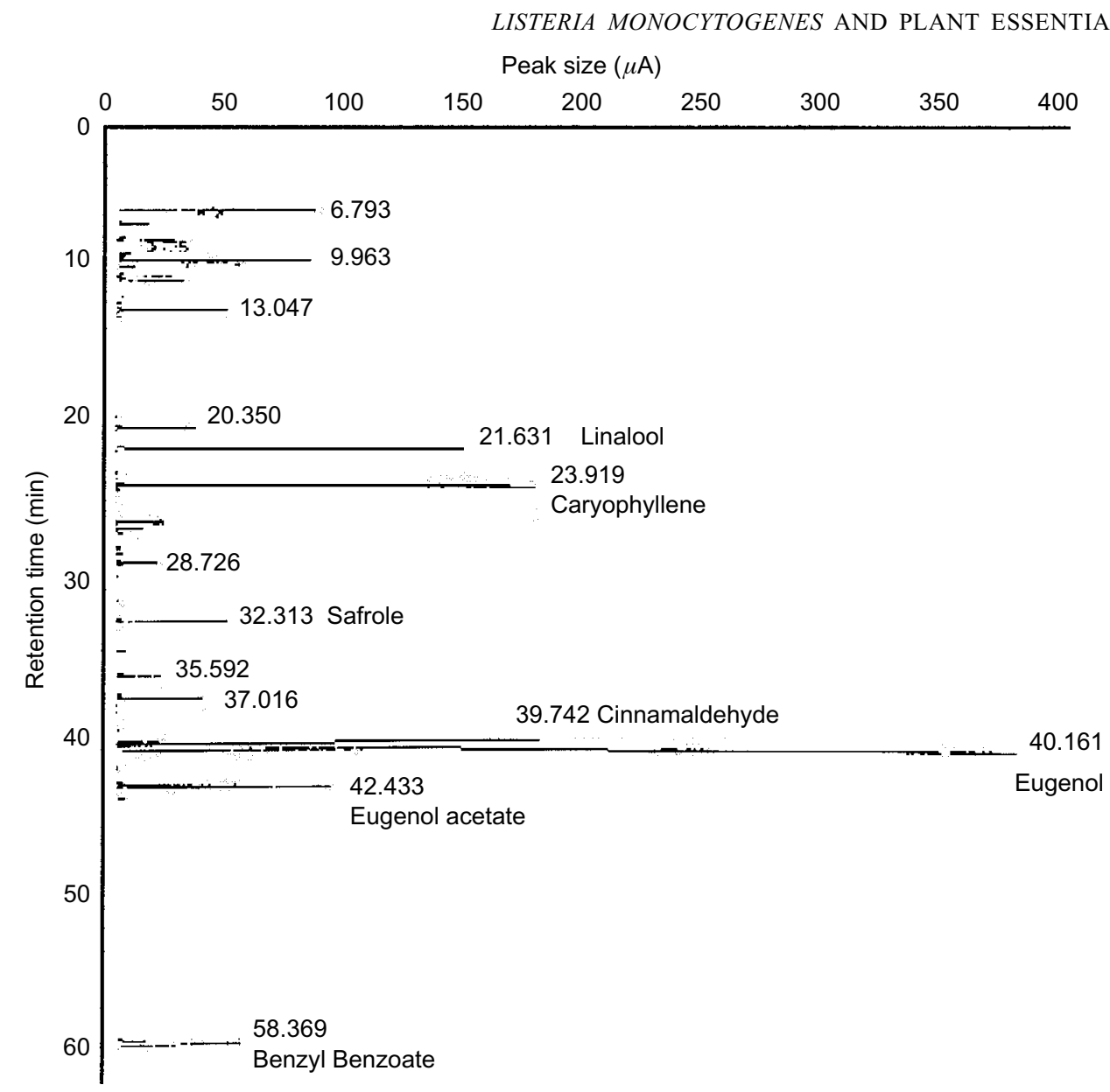

Fig. 2. Gas chromatography report for the composition of oil of cinnamon (Cinnamomum verum).

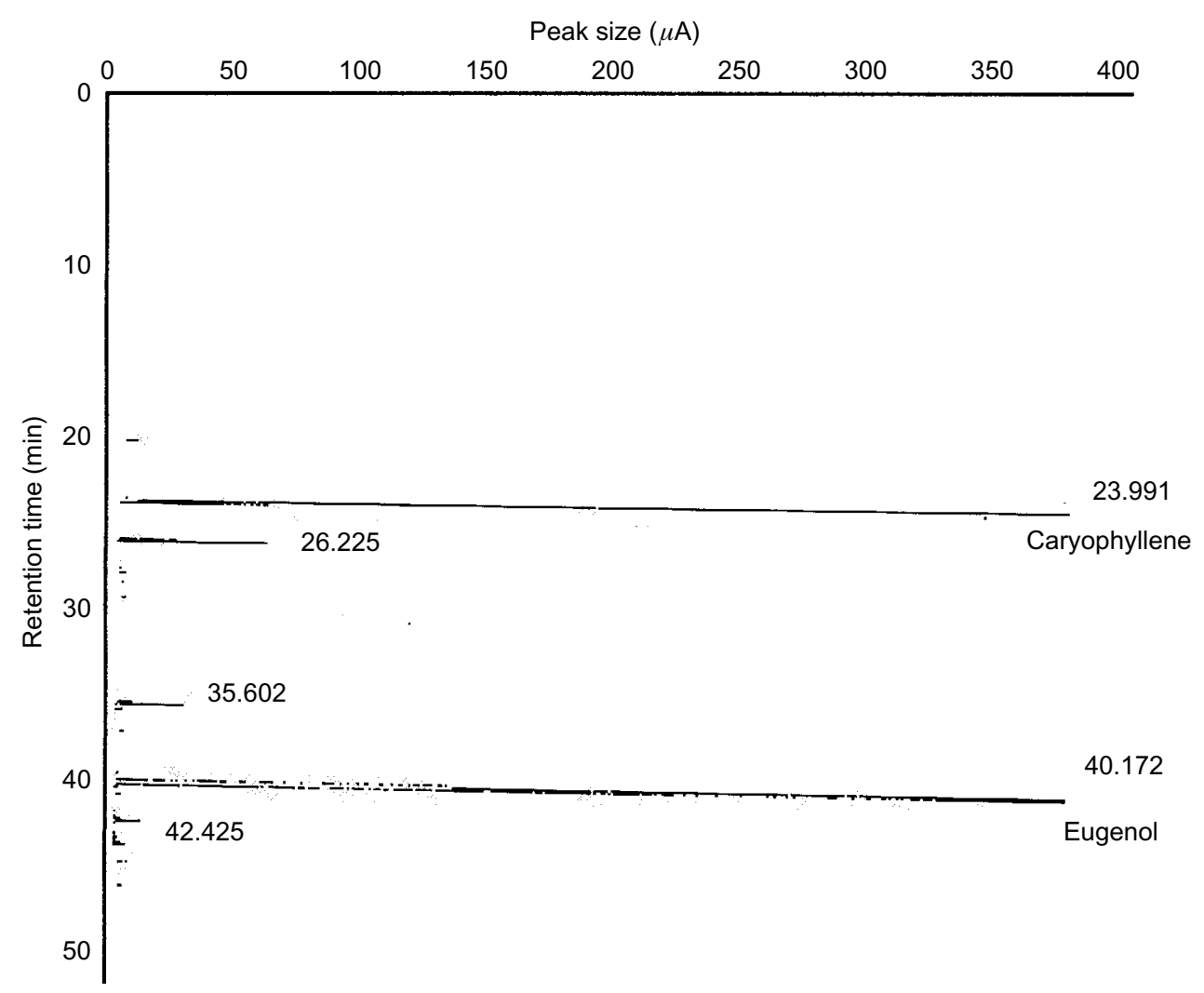

Fig. 3. Gas chromatography report for the composition of oil of clove (Syzygium aromaticum). 


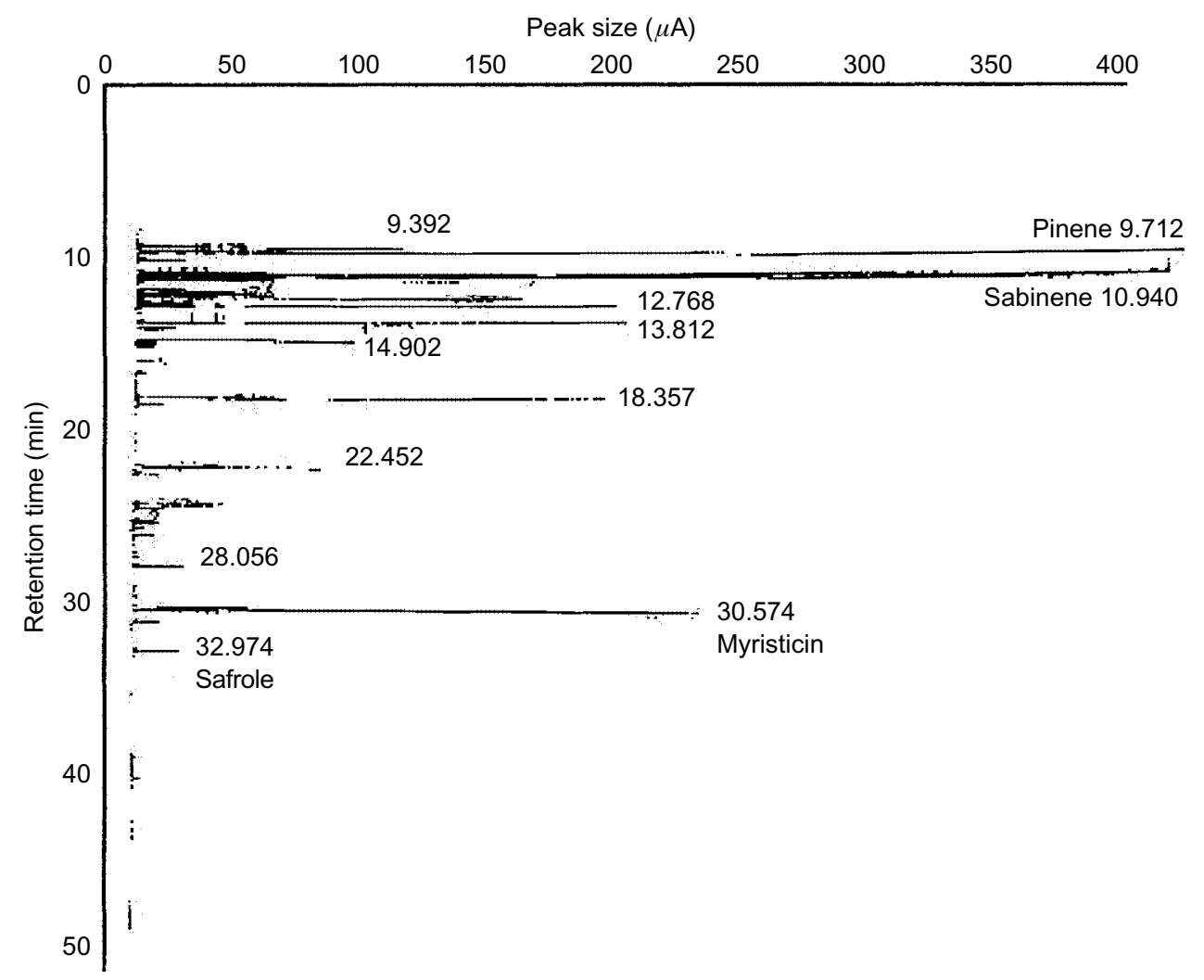

Fig. 4. Gas chromatography report for the composition of oil of nutmeg (Myristica fragrans).

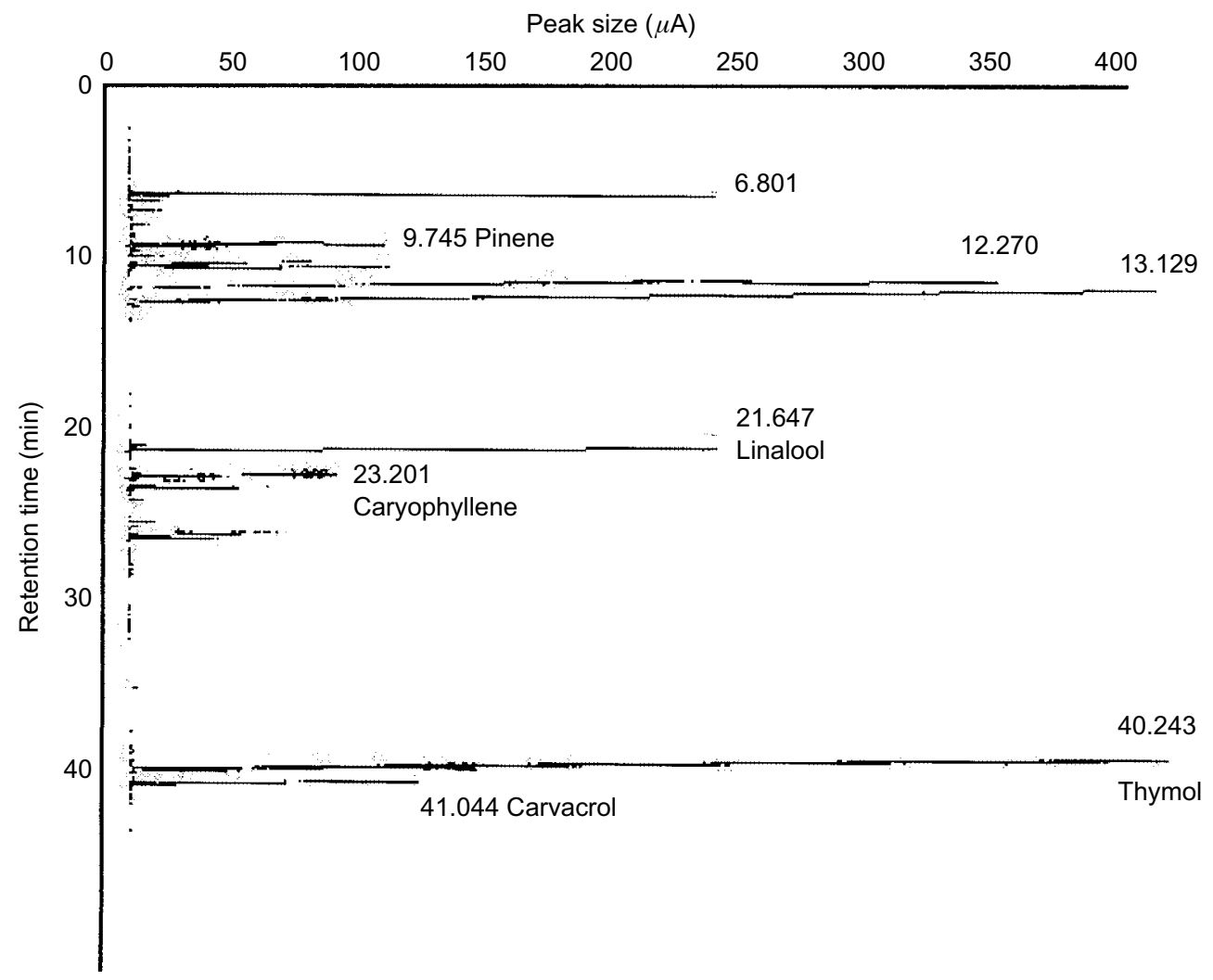

Fig. 5. Gas chromatography report for the composition of oil of thyme (Thymus vulgaris). 
Listeriolysin $O$ activity in the supernate after culture with subinhibitory concentrations of plant essential oils

Listeriolysin $\mathrm{O}$ activity was determined by a widely employed haemolysis assay [19]. Briefly, 1-ml samples of culture supernates were mixed with $485 \mu \mathrm{l}$ of phosphate-buffered saline (PBS; Sigma-Aldrich) containing $20 \mathrm{mM}$ cysteine (Sigma-Aldrich) and sheep erythrocytes (Oxoid) were added to achieve a final concentration of $1 \%$. Tubes were gently mixed by inversion, incubated at $37^{\circ} \mathrm{C}$ for $30 \mathrm{~min}$ and then centrifuged $(1000 \mathrm{~g})$ for $5 \mathrm{~min}$. The absorbance was read in triplicate at $550 \mathrm{~nm}$ with a Dynatech MR 500 plate reader. Experimental results were expressed as haemolytic units of activity. One haemolytic unit (HU) of activity was defined as the amount of activity that caused $50 \%$ haemolysis of the erythrocytes. To determine percentage haemolysis, controls were set up which contained 1\% erythrocytes and de-ionised water, which was taken as $100 \%$ haemolysis. Other controls contained PBS, TSB or TSB with subinhibitory concentrations of plant essential oils. No significant haemolysis was detected in these preparations.

Experiments were conducted to determine whether the reducing agent dithiothreitol (DTT; Sigma-Aldrich) could restore haemolysis lost as a result of culture with plant essential oils. The culture supernates were obtained as before and DTT was added to achieve a final concentration of $1 \mathrm{mM}$. The samples were mixed for $1 \mathrm{~h}$ at $37^{\circ} \mathrm{C}$ and the haemolytic activity was measured as before.

\section{Direct effect of plant essential oils on listeriolysin $O$ activity}

Experiments were conducted to determine whether plant essential oils directly inhibited the activity of listeriolysin O. Samples of the plant essential oils $(5 \mu \mathrm{l})$ were added to supernates from L. monocytogenes cultured in TSB only (therefore known to contain high levels of listeriolysin $\mathrm{O}$ ) to achieve concentrations of each oil greater than the subinhibitory concentrations. All tubes were incubated at $37^{\circ} \mathrm{C}$ for $1 \mathrm{~h}$ with constant mixing, and then the samples were left to settle for 15 min, enabling the plant essential oils to separate out. Then 1-ml samples were removed and haemolytic activity was measured as before.

\section{Determination of intracellular listeriolysin $O$ activity after culture with subinhibitory concentrations of plant essential oils}

Experiments were conducted to determine whether culture with plant essential oils prevented listeriolysin $\mathrm{O}$ synthesised in the cell being exported into the culture supernate. L. monocytogenes was cultured with subinhibitory concentrations of plant essential oils for $24 \mathrm{~h}$, the supernate was discarded, the cells were washed twice in PBS and resuspended in $10 \mathrm{ml}$ of PBS. Cells were lysed on ice by sonication for $5 \mathrm{~min}$ and examined by light microscopy to ensure that all cells were lysed. The lysate was centrifuged $(1600 \mathrm{~g})$ for $10 \mathrm{~min}$ to remove cell debris and the supernate was examined for haemolytic activity as above.

\section{Influence of plant essential oils on the phosphatidylcholine-specific phospholipase $C$ activity of L. monocytogenes}

Phosphatidylcholine-specific phospholipase $\mathrm{C}$ activity was determined by the method of Coffey et al. [20]. One $\mathrm{ml}$ of culture supernate was incubated with $2 \mathrm{ml}$ of a $10 \%$ solution of egg-yolk lecithin (Merck) and $7 \mathrm{ml}$ of $0.15 \mathrm{M} \mathrm{NaCl}$ (Sigma-Aldrich) at $37^{\circ} \mathrm{C}$ for $1 \mathrm{~h}$ and the amount of $\mathrm{H}^{+}$liberated was determined by titration and changes in $\mathrm{pH}$. Controls of TSB and TSB with subinhibitory concentrations of plant essential oils showed no significant liberation of $\mathrm{H}^{+}$.

\section{Reproducibility and statistics}

All measurements were conducted in triplicate within each experiment, and each experiment was performed on at least three separate occasions. Two-tailed Student's $t$ tests were used to analyse the data. Differences were judged to be statistically significant when $\mathrm{p} \leqslant 0.05$.

\section{Results}

To make a valid comparison of the influence of subinhibitory concentrations of plant essential oils on listeriolysin $\mathrm{O}$, it was necessary to ensure that the same cell numbers and quantity of extracellular protein were produced when cultured with plant essential oils as the control. At the concentrations used there was no reduction in bacterial growth (data not shown) nor in the amount of extracellular protein produced (Table 1). In contrast, listeriolysin $\mathrm{O}$ activity in the culture supernate was significantly reduced after culture with all five oils (Table 2). The greatest changes were observed after culture with the oils of clove and thyme with 55.9 and $52.1 \mathrm{HU} / \mathrm{ml}$, respectively, compared with $99.8 \mathrm{HU} / \mathrm{ml}$ observed with the control. Cells cultured with the oils of bay and cinnamon showed very similar

Table 1. The quantity of extracellular protein produced by L. monocytogenes after culture for $24 \mathrm{~h}$ with subinhibitory concentrations of plant essential oils

\begin{tabular}{lc}
\hline Culture conditions & $\begin{array}{c}\text { Mean }(\mathrm{SEM}) \text { extracellular } \\
\text { protein concentration }(\mu \mathrm{g} / \mathrm{ml})\end{array}$ \\
\hline Control & $34.66(0.54)$ \\
Oil of bay & $33.80(2.59)$ \\
Oil of cinnamon & $34.00(2.03)$ \\
Oil of clove & $33.66(1.36)$ \\
Oil of nutmeg & $34.20(1.11)$ \\
Oil of thyme & $34.62(0.54)$ \\
\hline
\end{tabular}


Table 2. Listeriolysin $\mathrm{O}$ activity in supernates from L. monocytogenes cultured with subinhibitory concentrations of plant essential oils

\begin{tabular}{lcl}
\hline & Mean (SEM) listeriolysin O activity (HU/ml) \\
\cline { 2 - 3 } Culture conditions & without DTT & with DTT $^{*}$ \\
\hline Control & $99.8(5.6)$ & $95.3(4.1)$ \\
Oil of bay & $63.1(3.1)^{\dagger}$ & $61.3(2.1)^{\dagger}$ \\
Oil of cinnamon & $63.7(4.6)^{\dagger}$ & $63.1(5.4)^{\dagger}$ \\
Oil of clove & $55.9(5.6)^{\dagger}$ & $56.9(5.5)^{\dagger}$ \\
Oil of nutmeg & $80.1(5.7)^{\dagger}$ & $83.5(4.6)^{\dagger}$ \\
Oil of thyme & $52.1(1.5)^{\dagger}$ & $57.3(4.1)^{\dagger}$ \\
\hline
\end{tabular}

*DTT was added to each supernate to achieve a final concentration of $1 \mathrm{mM}$, haemolytic activity was measured after incubation for $1 \mathrm{~h}$ at $37^{\circ} \mathrm{C}$.

${ }^{\dagger} \mathrm{p} \leqslant 0.05$ compared to corresponding control.

reductions in listeriolysin $\mathrm{O}$ activity with $63 \mathrm{HU} / \mathrm{ml}$. Oil of nutmeg proved to be the least influential with $80.1 \mathrm{HU} / \mathrm{ml}$. Table 2 also shows that the addition of DTT did not significantly alter the haemolytic activity in supernates from cells cultured with plant essential oils compared to samples without DTT. The plant essential oils were shown not to directly inhibit haemolytic activity present in supernates from cells cultured in TSB only and thus known to contain high levels of listeriolysin $O$ (Table 3). Similarly the plant essential oils did not inhibit the export of listeriolysin $\mathrm{O}$ from the cell, as $\leqslant 4 \mathrm{HU} / \mathrm{ml}$ was detected in all the samples of cell lysate (Table 4).

Fig. 6 shows $\mathrm{H}^{+}$production as a result of lecithin degradation by phosphatidylcholine-specific phospholi-

Table 3. Direct effect of plant essential oils on listeriolysin $\mathrm{O}$ activity

\begin{tabular}{lc}
\hline Plant essential oil & $\begin{array}{c}\text { Mean (SEM) listeriolysin } \\
\text { O activity }(\mathrm{HU} / \mathrm{ml})\end{array}$ \\
\hline Control & $102.4(5.6)$ \\
Oil of bay & $102.9(7.9)$ \\
Oil of cinnamon & $98.9(5.2)$ \\
Oil of clove & $103.1(5.1)$ \\
Oil of nutmeg & $100.2(5.3)$ \\
Oil of thyme & $102.4(2.4)$
\end{tabular}

The haemolytic activity observed after $5 \mu$ l of plant essential oil was added to $10 \mathrm{ml}$ of culture supernate from $L$. monocytogenes cultured without plant essential oils and incubated at $37^{\circ} \mathrm{C}$ for $1 \mathrm{~h}$, before the haemolytic activity was determined.

Table 4. Listeriolysin $\mathrm{O}$ activity in the cell lysate from L. monocytogenes cultured with subinhibitory concentrations of plant essential oils

\begin{tabular}{lc}
\hline Culture conditions & $\begin{array}{r}\text { Mean (SEM) listeriolysin O } \\
\text { activity }(\mathrm{HU} / \mathrm{ml})\end{array}$ \\
\hline Control & $3.3(0.1)$ \\
Oil of bay & $2.5(0.1)$ \\
Oil of cinnamon & $3.2(0.2)$ \\
Oil of clove & $3.5(0.2)$ \\
Oil of nutmeg & $3.6(0.1)$ \\
Oil of thyme & $4.0(0.3)$ \\
\hline
\end{tabular}

The haemolytic activity in the cell lysate obtained after L. monocytogenes was cultured for $24 \mathrm{~h}$ with subinhibitory concentrations of plant essential oils.

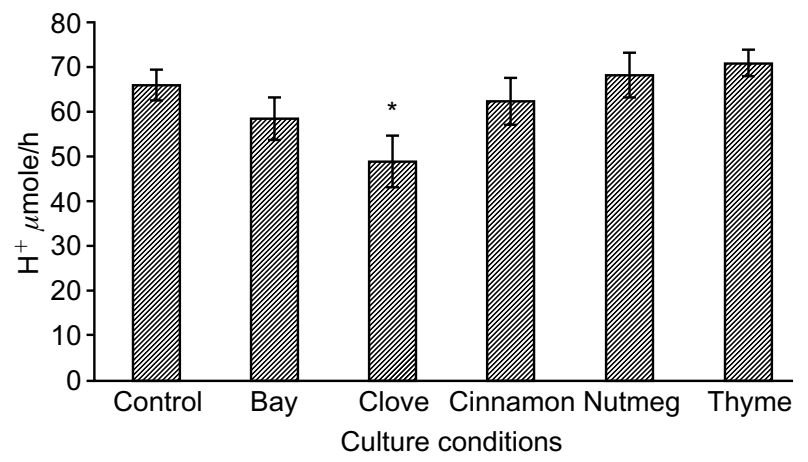

Fig. 6. Production of $\mathrm{H}^{+}$from egg yolk lecithin in $60 \mathrm{~min}$ $\left(\mu\right.$ mole $\left.\mathrm{H}^{+} / \mathrm{h}\right)$ by phosphatidylcholine-specific phospholipase $\mathrm{C}$ from L. monocytogenes cultured with subinhibitory concentrations of plant essential oils. ${ }^{*} \mathrm{p} \leqslant 0.05$ significant difference in $\mu$ mole $\mathrm{H}^{+} / \mathrm{h}$ compared with control.

pase $\mathrm{C} ; 65 \mu$ mole $\mathrm{H}^{+} / \mathrm{h}$ were produced by the control and no significant differences were detected for samples cultured with the oils of bay, cinnamon, nutmeg or thyme. A significant reduction of $17 \mu$ mole $\mathrm{H}^{+} / \mathrm{h}$ was observed for cells cultured with oil of clove.

\section{Discussion}

The data presented here show the ability of all five plant essential oils to significantly reduce the production of listeriolysin $\mathrm{O}$ at subinhibitory concentrations. The production of phosphatidylcholine-specific phospholipase $\mathrm{C}$ was inhibited by oil of clove. None of the oils used had a significant effect on the overall quantity of extracellular protein produced.

All the haemolytic activity detected in the culture supernates was assumed to be the result of listeriolysin O. Although phosphatidylcholine-specific phospholipase $\mathrm{C}$ has some haemolytic activity, it is not active against sheep erythrocytes, probably because they contain very little phosphatidylcholine [9]. Culture of L. monocytogenes with subinhibitory concentrations of all five plant essential oils, particularly oil of thyme, significantly reduced haemolysis indicative of listeriolysin $\mathrm{O}$. The results indicate that the inhibition was probably at the level of listeriolysin $\mathrm{O}$ production, rather than the oils interfering directly with listerioly$\sin \mathrm{O}$ activity. Firstly, activity was not restored by the addition of DTT, known to reverse activity lost as a result of oxidation or mercurials [19]. Secondly, the addition of plant essential oils to the supernate from $L$. monocytogenes cultured in TSB alone did not significantly reduce haemolysis (Table 3 ). This is the first account of listeriolysin $\mathrm{O}$ production being inhibited by plant essential oils. However, it is widely recognised that production is influenced by other factors including glucose concentration [21,22], $\mathrm{NaCl}[23,24]$, cellobiose [25] and $\beta$-lactam antibiotics [26]. Kouassi and Shelef reported that sorbate suppressed listeriolysin O secretion and its activation by cysteine [27]. These findings led them to suggest that the addition of sorbate 
to foods could reduce listeriolysin $\mathrm{O}$ production. Similar conclusions could be drawn from the data presented here regarding the addition of plant essential oils.

A significant reduction in $\mathrm{H}^{+}$production resulting from the breakdown of lecithin by phosphatidylcholinespecific phospholipase $\mathrm{C}$ was detected only with cells previously cultured with oil of clove. It has been reported previously that $\mathrm{pH}$, temperature, salt concentration and nutrient availability all have a significant impact on the production of phosphatidylcholinespecific phospholipase C [20]. Hence, it is not surprising that production can also be influenced by the presence of antimicrobial agents such as plant essential oils. It was possible that the inhibition observed did not result from oil of clove directly inhibiting the production or activity of the phospholipase perse, but rather the metalloprotease. The metalloprotease activates the precursor of the phospholipase secreted by the cells to the active enzyme [28]. The reduction in phosphatidylcholine-specific phospholipase $\mathrm{C}$ activity by oil of clove has the potential to limit the cell-to-cell spread of L. monocytogenes, especially when coupled with the significant reduction in listeriolysin $\mathrm{O}$.

It is known that a number of virulence genes in $L$. monocytogenes - including hly encoding listeriolysin $\mathrm{O}$, plcB encoding phosphatidylcholine-specific phospholipase $\mathrm{C}, \mathrm{mpl}$ encoding metalloprotease and act $\mathrm{A}$ which encodes a protein necessary for actin polymerisation - are positively regulated by PrfA, a transcriptional activator $[29,30]$. Because oil of clove was the only oil to inhibit the production of both toxins, it was possibly the only one to act at the level of genetic regulation. However, the remaining oils may have directly or indirectly inhibited hly specifically rather than the regulation of this gene. Similarly, cellobiose has been reported to repress hly [25] but not phosphatidylcholine-specific phospholipase C [20].

Another possible explanation for the inhibition of toxin production was disruption at the ribosomal level. It is believed that extracellular proteins are generally synthesised on membrane-associated ribosomes, whereas intracellular proteins are synthesised on cytoplasmic ribosomes [31]. Thus, toxin production is sensitive to changes in the membrane caused by plant essential oils, and the membrane is recognised as an important target site for many plant essential oils $[32,33]$. Furthermore, components of plant essential oils actually penetrating the membrane would more readily interact with membrane-bound ribosomes than cytoplasmic ribosomes. Any changes to the cell membrane caused by the plant essential oils did not interfere with the cell's ability to export extracellular proteins, as no change in intracellular haemolytic activity was detected (Table 4) and, furthermore, there was no change in total extracellular protein concentration (Table 1).
The work presented here shows the potential of selected plant essential oils at subinhibitory concentrations to reduce the pathogenicity of L. monocytogenes by reducing the production of two key factors, listeriolysin $\mathrm{O}$ and phosphatidylcholine-specific phospholipase C. Reductions in pathogenicity could have important implications when considering potential applications in the food and pharmaceutical industries, especially at a time when there is already considerable interest in plant essential oils because of their antimicrobial action $[12,13]$ and antioxidant properties.

We acknowledge F.D. Copeland and Sons, Colanol House, 5 Westfield Street, London for the generous supply of plant essential oils.

\section{References}

1. Lamont RJ, Postlethwaite R, MacGowan AP. Listeria monocytogenes and its role in human infection. J Infect 1988; 17: $7-28$.

2. McLauchlin J. The pathogenicity of Listeria monocytogenes: a public health perspective. Rev Med Microbiol 1997; 8: 1-14.

3. Jurado RL, Farley MM, Pereira E et al. Increased risk of meningitis and bacteremia due to Listeria monocytogenes in patients with human immunodeficiency virus infection. Clin Infect Dis 1993; 17: 224-227.

4. Gellin BG, Broome CV. Listeriosis. JAMA 1989; 261: 1313-1320.

5. Lingnau A, Domann E, Hudel $\mathrm{M}$ et al. Expression of the Listeria monocytogenes EGD inlA and inlB genes, whose products mediate bacterial entry into tissue culture cell lines, by PrfA-dependent and -independent mechanisms. Infect Immun 1995; 63: 3896-3903.

6. Ruhland GJ, Hellwig M, Wanner G, Fiedler F. Cell-surface location of Listeria-specific protein p60-detection of Listeria cells by indirect immunofluorescence. J Gen Microbiol 1993; 139: 609-616.

7. Smith GA, Marquis H, Jones S, Johnston NC, Portnoy DA, Goldfine H. The two distinct phospholipases C of Listeria monocytogenes have overlapping roles in escape from a vacuole and cell-to-cell spread. Infect Immun 1995; 63: 4231-4237.

8. Camilli A, Goldfine H, Portnoy DA. Listeria monocytogenes mutants lacking phosphatidylinositol-specific phospholipase C are avirulent. J Exp Med 1991; 173: 751-754.

9. Geoffroy C, Raveneau J, Beretti J-L et al. Purification and characterization of an extracellular 29-kilodalton phospholipase C from Listeria monocytogenes. Infect Immun 1991; 59: 2382-2388.

10. Portnoy DA, Chakraborty T, Goebel W, Cossart P. Molecular determinants of Listeria monocytogenes pathogenesis. Infect Immun 1992; 60: 1263-1267.

11. Sheehan B, Kocks C, Dramsi S et al. Molecular and genetic determinants of the Listeria monocytogenes infection process. Curr Top Microbiol Immunol 1994; 192: 187-216.

12. Kumar M, Berwal JS. Sensitivity of food pathogens to garlic (Allium sativum). J Appl Microbiol 1998; 84: 213-215.

13. Smith-Palmer A, Stewart J, Fyfe L. Antimicrobial properties of plant essential oils and essences against five important foodborne pathogens. Lett Appl Microbiol 1998; 26: 118-122.

14. Deans SG, Ritchie G. Antibacterial properties of plant essential oils. Int J Food Microbiol 1987; 5: 165-180.

15. González-Fandos E, García-López ML, Sierra ML, Otero A. Staphylococcal growth and enterotoxins (A-D) and thermonuclease synthesis in the presence of dehydrated garlic. $J$ Appl Bacteriol 1994; 77: 549-552.

16. De Wit JC, Notermans S, Gorin N, Kampelmacher EH. Effect of garlic oil or onion oil on toxin production by Clostridium botulinum in meat slurry. J Food Protect 1979; 42: 222-224.

17. Lis-Balchin M, Deans SG. Bioactivity of selected plant essential oils against Listeria monocytogenes. J Appl Microbiol 1997; 82: 759-762.

18. Bradford MM. A rapid and sensitive method for the quantitation of microgram quantities of protein utilizing the 
principle of protein-dye binding. Anal Biochem 1976; 72 248-254.

19. Geoffroy C, Gaillard J-L, Alouf JE, Berche P. Purification, characterization, and toxicity of the sulfhydryl-activated hemolysin Listeriolysin $\mathrm{O}$ from Listeria monocytogenes. Infect Immun 1987; 55: 1641-1646.

20. Coffey A, Rombouts FM, Abee T. Influence of environmental parameters on phosphatidylcholine phospholipase $\mathrm{C}$ production in Listeria monocytogenes: a convenient method to differentiate L. monocytogenes from other Listeria species. Appl Environ Microbiol 1996; 62: 1252-1256.

21. Behari J, Youngman P. Regulation of hly expression in Listeria monocytogenes by carbon sources and $\mathrm{pH}$ occurs through separate mechanisms mediated by PrfA. Infect Immun 1998; 66: $3635-3642$

22. Datta AR, Kothary MH. Effects of glucose, growth temperature, and $\mathrm{pH}$ on listeriolysin $\mathrm{O}$ production in Listeria monocytogenes. Appl Environ Microbiol 1993; 59: 3495-3497.

23. Myers ER, Dallmier AW, Martin SE. Sodium chloride, potassium chloride, and virulence in Listeria monocytogenes. Appl Environ Microbiol 1993; 59: 2082-2086.

24. Dallmier AW, Martin SE. Catalase, superoxide dismutase, and hemolysin activities and heat susceptibility of Listeria monocytogenes after growth in media containing sodium chloride. Appl Environ Microbiol 1993; 56: 2807-2810.

25. Park SF, Kroll RG. Expression of listeriolysin and phosphatidylinositol-specific phospholipase $\mathrm{C}$ is repressed by the plantderived molecule cellobiose in Listeria monocytogenes. Mol Microbiol 1993; 8: 653-661.
26. Nichterlein T, Domann E, Kretschmar M et al. Subinhibitory concentrations of $\beta$-lactams and other cell-wall antibiotics inhibit listeriolysin production by Listeria monocytogenes. Int $J$ Antimicrob Agents 1996; 7: 75-81.

27. Kouassi Y, Shelef LA. Listeriolysin O secretion by Listeria monocytogenes in the presence of cysteine and sorbate. Lett Appl Microbiol 1995; 20: 295-299.

28. Marquis H, Doshi V, Portnoy DA. The broad-range phospholipase $\mathrm{C}$ and a metalloprotease mediate listeriolysin Oindependent escape of Listeria monocytogenes from a primary vacuole in human epithelial cells. Infect Immun 1995; 63: 4531-4534.

29. Renzoni A, Klarsfeld A, Dramsi S, Cossart P. Evidence that PrfA, the pleiotropic activator of virulence genes in Listeria monocytogenes, can be present but inactive. Infect Immun 1997; 65: 1515-1518.

30. Chakraborty T, Leimeister-Wächter M, Domann E et al. Coordinate regulation of virulence genes in Listeria monocytogenes requires the product of the prfA gene. JBacteriol 1992; 174: 568-574.

31. Fishman Y, Rottem S, Citri N. Preferential suppression of normal exoenzyme formation by membrane-modifying agents. $J$ Bacteriol 1980; 141: 1435-1438.

32. Cox SD, Gustafson JE, Mann CM et al. Tea tree oil causes $\mathrm{K}^{+}$leakage and inhibits respiration in Escherichia coli. Lett Appl Microbiol 1998; 26: 355-358.

33. Ultee A, Gorris LGM, Smid EJ. Bactericidal activity of carvacrol towards the food-borne pathogen Bacillus cereus. J Appl Microbiol 1998; 85: 211-218. 